\title{
KESUKARAN PERMOHONAN ZAKAT DALAM KALANGAN PENDUDUK FLAT KOS RENDAH DI KAWASAN PARLIMEN BATU, LEMBAH PANTAI DAN SETIAWANGSA
}

\author{
Muhammad Adib Mohd Zaki ${ }^{a \star}$, Mohd Ali Mohd Noor ${ }^{\mathrm{b}}$, Hairunnizam Wahid ${ }^{\mathrm{c}}$ \& \\ Muhammad Syafiq Muhamad Sham ${ }^{d}$ \\ ${ }^{\mathrm{a}, \mathrm{b}, \mathrm{c}, \mathrm{d}}$ Fakulti Ekonomi dan Pengurusan, Universiti Kebangsaan Malaysia \\ A PEER-REVIEWED ARTICLE \\ (RECEIVED - MAY 20, 2020; REVISED - AUGUST 10, 2020; ACCEPTED - OCTOBER 1, 2020)
}

\begin{abstract}
Poverty and the denied rights of low-cost flats residents, particularly in Kuala Lumpur, have become heated topics discussed among academicians and politicians. The main purpose of this study is to identify the contributing factors towards the ineffectiveness of zakat application among low-cost flats residents in Parlimen Batu, Lembah Pantai and Setiawangsa. The collected data is obtained through a survey form distributed to 139 respondents among the residents of the low-cost flats in the named parliamentary constituencies via random sampling together with data analysis involving binomial logistic regression. Based on this statistic, there are a few factors such as age, the application process, facilities, and zakat services. Other than that, this study proves that majority of the respondents agree to establish a committee of amil kariah at their residences to ease the zakat management, as well as the process of identifying asnaf and enhancing the quality of zakat facilities and services. Therefore, few alternatives and policy implications have been suggested in this study as a method of improvement in assisting the denied yet welldeserving group of asnaf in the area.
\end{abstract}

\begin{abstract}
ABSTRAK
Kemiskinan dan penafian hak penduduk flat kos rendah lebih-lebih lagi di Kuala Lumpur telah menjadi satu topik yang hangat dibicarakan dalam kalangan ahli politik dan akademik. Tujuan utama kajian ini dilaksanakan adalah untuk mengenal pasti faktor-faktor kesukaran permohonan zakat dalam kalangan penduduk flat kos rendah di kawasan Parlimen Batu, Lembah Pantai dan Setiawangsa. Data-data yang digunakan adalah melalui penggunaan instrumen borang soal selidik ke atas 139 responden yang terdiri daripada penduduk flat kos rendah di kawasan tersebut secara sampel rawak dengan analisis data yang melibatkan penggunaan regrasi logistik berbentuk binomial. Berdasarkan hasil statistik menunjukkan terdapat beberapa faktor yang mempengaruhi kesukaran penduduk flat kos rendah dalam membuat permohonan zakat di kawasan tersebut seperti faktor umur, proses permohonan zakat, kemudahan dan perkhidmatan zakat. Selain itu, hasil kajian ini juga menunjukkan majoriti responden bersetuju untuk menubuhkan satu ahli jawatankuasa amil kariah di kawasan flat mereka untuk menguruskan hal ehwal zakat serta memudahkan lagi proses pencarian golongan asnaf dan meningkatkan kualiti kemudahan dan perkhidmatan zakat itu sendiri. Oleh itu, beberapa cadangan dan implikasi dasar turut dicadangkan dalam kajian ini sebagai langkah penambahbaikkan bagi membantu golongan yang telah dinafikan hak yang sewajarnya mereka terima.
\end{abstract}

- Corresponding author: Muhammad Adib Mohd Zaki, Fakulti Ekonomi dan Pengurusan, Universiti Kebangsaan Malaysia, 43000 Bangi, Selangor. Email: p91666@siswa.ukm.edu.my 


\section{MUHAMMAD ADIB MOHD ZAKI, MOHD ALI MOHD NOOR, HAIRUNNIZAM WAHID \& MUHAMMAD SYAFIQ MUHAMAD SHAM}

Kata kunci: Kemiskinan bandar, penduduk flat kos rendah, kesukaran membuat permohonan zakat, amil kariah

\section{Pendahuluan}

Zakat disifatkan sebagai satu kemudahan kebajikan yang disediakan disajikan oleh ekonomi Islam sebagai suntikan terhadap sebarang kemungkinan yang akan dihadapi oleh masyarakat melalui pengedaran harta dan pendapatan. Zakat menurut bahasa berasal dari kata bertambah (ziyadah) dan tumbuh (nama'). Selain itu, ia juga berasal dari kata kebaikan, keberkatan, pembersihan atau penyucian (thathhir). Justeru, penggunaan makna-makna ini telah pun dinyatakan di dalam Al-Quran dan As-Sunnah di mana Allah S.W.T berfirman yang bermaksud:

$$
\text { قََْْ أَفْلَحَ مَن زَكَّاهَا }
$$

"Sesungguhnya berjayalah orang yang menyucikan jiwanya."

(Surah Asy-Syam:9)

Ertinya, seseorang hamba yang membersihkan jiwanya melalui ketaatan kepada perintah Allah S.W.T dan menjauhi segala laranganNya akan menemui hakikat sebuah kebahagian sama ada di dunia atau di akhirat.

Zakat merupakan salah satu instrumen bantuan yang dikeluarkan oleh golongan yang berkemampuan dan diberikan kepada golongan tertentu seperti yang telah tertulis di dalam Al-Quran di mana Allah S.W.T berfirman:

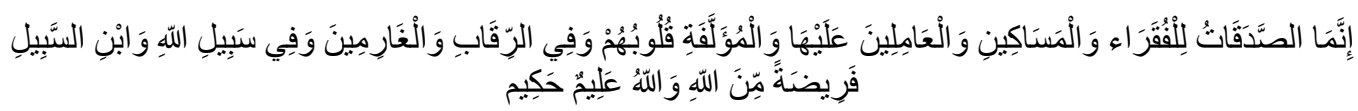

"Sesungguhnya sedekah - sedekah (zakat) itu hanyalah untuk orang-orang fakir, dan orang-orang miskin, dana amil-amil yang mengurusnya, dan orang-orang mu'allaf yang dijinakkan hatinya, dan hamba-hamba yang hendak memerdekakan dirinya, dan orangorang yang berhutang, dan untuk (dibelanjakan pada) jalan Allah, dan orang- orang musafir (yang keputusan) dalam perjalanan. (ketetapan yang demikian itu ialah) sebagai satu ketetapan (yang datangnya) dari Allah. Dan (ingatlah) Allah Maha Mengetahui, lagi Maha Bijaksana."

(Surah At-Taubah:60)

Tafsiran ayat tersebut dapat disimpulkan bahawa terdapat lapan golongan manusia yang berhak untuk menerima zakat. Antaranya adalah al-fuqara (orang fakir), al-masakin (orang yang miskin), amil, muallaf yang perlu dijinakkan hatinya, al-riqab (hamba), al-gharimin (orang yang memiliki hutang), fisabilillah (orang yang berjuang di jalan Allah SWT) dan akhirnya ibn sabil (musafir yang sedang dalam perjalanan). Menurut mazhab Imam Syafie, dana zakat didahulukan kepada tiga golongan di mana golongan ketiga tersebut adalah amil. Amil akan mengambil tempat ketiga selepas asnaf fakir dan miskin berdasarkan hujah-hujah berkenaan dengan agihan yang dilaksanakan kepada tiga golongan asnaf tersebut. Namun secara umumnya terdapat empat golongan yang perlu diutamakan terlebih dahulu dalam pengagihan dana zakat iaitu al-fuqara (golongan fakir), al-masakin (golongan miskin), al-gharimin (golongan berhutang), dan ibn sabil (golongan bermusafir) (Mohamad Uda, 2005; Eza Ellany et al. 2014). Oleh itu, demi mencapai keadilan yang optimum, institusi zakat perlu memastikan dana zakat diagihkan terlebih dahulu kepada asnaf di atas sebelum asnaf selebihnya yang dinyatakan dalam Al-Quran. 
Penubuhan institusi zakat adalah untuk memudahkan lagi pengurusan agihan zakat kepada golongan yang berkelayakan. Namun, institusi zakat sebagai satu badan yang menguruskan zakat bukanlah sesuatu kemestian menurut kebanyakan aliran pemikiran perundangan Islam (Zayas, 2003). Akan tetapi setiap muslim wajib mengeluarkan zakat iaitu berbentuk menyerahkan sebahagian harta mereka kepada yang memerlukan seperti yang telah ditetapkan di dalam Al-Quran. Sejak kewafatan Rasulullah S.A.W, khalifah Islam yang keempat iaitu Saidina Abu Bakar Al-Siddiq sangat tegas terhadap perlaksanaan zakat dengan memerangi golongan-golongan yang ingkar terhadap pembayaran zakat. Pengurusan dana zakat yang cekap dan efisen sangat penting bagi menarik minat pembayar zakat untuk membayar zakat supaya dapat membasmi masalah kemiskinan dan meningkatkan kualiti modal insan khususnya dari sudut ekonomi. Selepas itu, setiap negeri di Malaysia mempunyai sistem pentadbiran dan pengurusan yang berbeza kerana ia terletak di bawah bidang kuasa kerajaan negeri seperti yang telah termaktub di dalam Perlembagaan Malaysia. Oleh itu, pihak zakat harus memastikan tahap pengurusan dapat dilakukan dengan professional, adil dan cekap. Di samping itu, pihak zakat juga perlu kearah membentuk penerapan kepercayaan kepada institusi zakat bagi menarik lagi minat pembayar zakat.

Dilema zakat bukanlah satu wacana yang baru dalam era moden pada hari ini kerana kini seluruh negara sedang berhadapan dengan cabaran revolusi industri 4.0 di mana pasti akan wujud segelintir masyarakat atau negara yang akan ketinggalan ke belakang. Pengurusan zakat juga tidak dapat lari daripada tempias revolusi tersebut kerana aspek pengurusannya haruslah selari dengan pembangunan teknologi semasa bagi mendidik masyarakat mendepani cabaran tersebut. Kini pusat zakat mengalami masalah dari sudut pengagihan zakat yang tidak boleh diselesaikan dalam masa setahun kerana pembayar zakat di Malaysia lebih gemar membuat pembayaran zakat pada akhir hujung tahun (Noor et al., 2015). Masalah ini juga merupakan masalah yang sangat serius kerana ia akan memberi impak yang negatif terhadap jumlah kutipan zakat apabila pembayar zakat tidak lagi percaya terhadap institusi tersebut dalam membasmi masalah kemiskinan. Bentuk kemiskinan pula tidak lagi seperti dahulu di mana fokusnya hanya pada kawasan desa sahaja tetapi kini ia juga melibatkan kawasan bandar (Muhammed Abdul Khalid et al. 2018) kerana peluang pekerjaan yang lebih berpusat di bandar hingga menyebabkan semakin ramai yang berhijrah ke sana. Lantas, kerajaan telah melaksanakan pelbagai dasar bagi kelangsungan rakyat miskin di bandar dengan membina lebih banyak flat kos rendah sekaligus menangani masalah rumah setinggan dan perumahan mampu milik.

Namun penduduk flat kos rendah masih lagi berada dalam keadaan serba kekurangan dari segi pemakanan, kesihatan, keselamatan dan keadaan hidup. Berdasarkan kaji selidik yang diterbitkan oleh UNICEF menunjukkan 99.75\% kanak-kanak di flat kos rendah di Kuala Lumpur hidup dalam keadaan miskin (Muhammed Abdul Khalid et al. 2018). Walaupun kadar kemiskinan kebangsaan adalah 0.4\% tetapi kelompok kemiskinan masih lagi wujud seperti kelompok masyarakat Orang Asli, Bumiputera di Sabah dan Sarawak. Kajian ini berjaya membuktikan bahawa masih terdapat segelintir masyarakat yang hidup melarat dan tidak dapat menikmati kekayaan negara dengan adil walaupun pendapatan negara semakin meningkat. Selain itu, kebanyakan penduduk ini juga hanya mengharapkan bantuan daripada kos Bantuan Rakyat 1Malaysia (BR1M) iaitu seramai 68\% manakala hanya 1\% sahaja yang menerima bantuan daripada pusat zakat. Selepas itu, tindak balas dasar dan pilihan program yang digubal oleh pihak berkuasa untuk mengurangkan kemiskinan di bandar tidak selaras dengan objektif dasar utama untuk mengurangkan isi rumah miskin. Oleh itu, permasalahan isu ini perlu diketengahkan untuk diberikan perhatian oleh pihak yang berwajib supaya dapat menyediakan dasar kebajikan yang adil bagi menangani isu ini.

Rumusnya, cabaran berkaitan dengan wacana zakat akan sentiasa berterusan terutama sekali apabila melibatkan penduduk flat kos rendah yang berpendapatan rendah kerana ia melibatkan satu wacana lain yang sangat kompleks iaitu kemiskinan bandar. Justeru, penulisan artikel ini adalah untuk menimbulkan 


\section{MUHAMMAD ADIB MOHD ZAKI, MOHD ALI MOHD NOOR, HAIRUNNIZAM WAHID \& MUHAMMAD SYAFIQ MUHAMAD SHAM}

kesedaran kepada pihak-pihak yang berwajib bahawa isu ini perlu diberi khusus bagi menyelesaikan permasalahan ini kelak dan bukanlah untuk mencari kesalahan mana-mana pihak. Oleh itu, tujuan utama kertas kerja ini adalah untuk mengenal pasti faktor-faktor kesukaran permohonan zakat dalam kalangan penduduk flat kos rendah di kawasan Parlimen tersebut. Bahagian berikutnya akan mengupas beberapa kajian lepas, diikuti dengan kaedah kajian, hasil kajian dan perbincangan serta cadangan dasar sebelum diakhiri dengan kesimpulan kajian.

\section{Kajian lepas}

Kajian terdahulu telah membuktikan bahawa masalah kutipan zakat telah berjaya ditangani dengan jumlah kutipan sebanyak RM589 juta pada tahun 2016 berbanding RM492 juta pada tahun 2013 (Laporan zakat, Pusat Pungutan Zakat, 2016). Banyak alternatif yang telah dilakukan oleh pusat zakat terutama sekali dalam melaksanakan lokalisasi tadbir urus zakat di masjid dengan memberikan kuasa memungut dan mengagih kepada kakitangan di lokaliti tempatan seperti daerah dan mukim kampung. Hal ini menyebabkan pemusatan kuasa dalam pengurusan zakat dapat dikurangkan dan memudahkan akses masyarakat setempat (Muhammad Syukri, 2006). Namun proses pengagihan zakat masih lagi menjadi isu kerana karenah birokrasi, pengagihan zakat yang tidak menyeluruh kepada golongan asnaf dan kurang publisiti permohonan zakat berbanding dengan pembayaran zakat (Embong et al., 2013). Selepas itu, trend pembayaran zakat di Malaysia lebih cenderung dilakukan pada hujung tahun hingga menyebabkan pusat zakat tidak mempunyai waktu yang cukup bagi mencari golongan asnaf untuk mengurangkan jumlah lebihan zakat setiap tahun (Noor et al., 2015) dan pusat zakat juga tidak mempunyai sumber tenaga kerja yang mencukupi bagi melaksanakan proses pengagihan tersebut. Justeru, jika isu pengagihan ini tidak diselesaikan dengan segera ia akan menimbulkan persepsi yang negatif dalam kalangan pembayar zakat.

Kesan daripada persepsi negatif ini akan meningkatkan kebarangkalian pembayar zakat tidak lagi mahu membayar zakat dan mereka lebih gemar membayar secara langsung kepada golongan asnaf. Lebih parah lagi apabila pembayaran tersebut hanya tertumpu kepada asnaf fakir dan miskin sahaja hingga mengabaikan enam lagi asnaf yang lain disebabkan oleh masalah kekurangan maklumat asnaf dalam kalangan pembayar zakat (Hairunnizam et al., 2010). Ia juga boleh menyebabkan jumlah pungutan zakat semakin berkurangan sehingga menjejaskan kebajikan golongan asnaf, lebih-lebih lagi apabila melibatkan penduduk flat kos rendah yang juga turut terpinggir dengan jumlah penduduk yang sangat padat. Mereka ini merupakan golongan yang sangat kompleks bagi pihak pengurusan zakat untuk mengenal pasti keberadaan mereka kerana faktor pembangunan, keselamatan dan masalah sosial hingga menyebabkan mereka banyak menghabiskan masa di dalam rumah daripada terlibat dengan sebarang program kemasyarakatan. Perkara ini terbukti benar apabila kemiskinan akan menyebabkan seseorang akan beranggapan bahawa mereka diketepikan daripada proses membuat keputusan dalam masyarakatnya sendiri, diskriminasi daripada masyarakat, hilang rasa kesepunyaan kepada masyarakat dan mudah terdedah kepada jenayah bandar (UN-HABITAT, 2003). Justeru, kita dapat melihat bagaimana keadaan strata di sana yang tidak tersusun dengan proses penyelangaraan yang tidak diurus dengan baik.

Menurut Khalid et al. (2018) kebanyakan bantuan yang diterima oleh penduduk flat kos rendah adalah terdiri daripada bantuan Bantuan Rakyat 1Malaysia (BR1M) atau kini dikenali dengan Bantuan Sara Hidup Rakyat (BSH) iaitu sebanyak 68 peratus manakala hanya 1 peratus sahaja yang menerima bantuan daripada zakat. Ini menunjukkan bahawa masalah pengagihan zakat masih lagi wujud sehingga kini. Malah kaji selidik ini juga mendapati kira-kira 22\% kanak-kanak bawah umur 5 tahun di flat kos rendah mengalami pertumbuhan yang terbantut, $15 \%$ mengalami kurang berat badan dan $23 \%$ sama ada mengalami berat badan berlebihan ataupun obesiti. Pusat zakat sewajarnya mengutamakan golongan seperti ini kerana itu merupakan fungsi utama kewujudan institusi tersebut bagi menangani masalah kemiskinan yang bukan sahaja melihat daripada aspek pendapatan semata-mata, tetapi turut 
mempertimbangkan aspek pendidikan, kesihatan dan sebagainya. Namun perkara sebaliknya berlaku dan ini akan menyebabkan ketidakpercayaan masyarakat terhadap pusat zakat yang tidak berfungsi dengan baik. Malah menurut Za'aba (2015) sesebuah tamandun itu akan runtuh jika masyarakatnya sudah hilang kepercayaan terhadap sesebuah institusi sepertimana yang telah berlaku terhadap Tamadun Rom pada masa dahulu.

Kesimpulannya, kajian Khalid et al. (2018) tidak menyatakan sebab musabab mengenai kewujudkan masalah ini. Pertikaian kajian itu hanya berlegar sekitar isu bantuan BR1M yang menunjukkan seramai 34 peratus isi rumah yang berpendapatan bawah RM4,000 tidak menerima BR1M. Justeru, kajian mengenai faktor-faktor ketidakberkesanan pengagihan zakat kepada golongan asnaf masih kurang diteliti oleh para penkaji di Malaysia. Namun kajian mengenai faktor-faktor terhadap keberkesanan perlaksanaan zakat telah pun dilakukan oleh penkaji terdahulu iaitu melihat dari sudut perlaksanaan projek Taman Desa Asnaf fakir dan miskin di Perlis. Mereka meneliti keberkesanan itu atas faktor kualiti hidup dan modal insan yang lebih melihat ke arah sudut yang positif (Hairunnizam Wahid, 2018). Justeru, bagi mengisi kelompongan tersebut penyelidik akan mengenal pasti faktor-faktor yang menyebabkan peratus penerimaan zakat yang sangat rendah dengan melihat dari sudut kesukaran permohonan zakat dalam kalangan penduduk flat kos rendah supaya ia dapat memberikan pencerahan kepada pihak berkuasa bagi memudahkan proses perlaksanaan dasar pada masa hadapan.

\section{Metodologi}

Borang kaji selidik secara berstruktur telah dibentuk dan diagihkan kepada penduduk flat kos rendah di sekitar Kawasan Dun Batu, Lembah Pantai dan Setiawangsa secara pensampelan rawak mudah yang terbahagi kepada 5 bahagian iaitu maklumat mengenai demografi, kemudahan \& perkhidmatan zakat, pengiklanan zakat, penggunaan sistem e-zakat dan proses permohonan zakat. Jadual 1 menunjukkan setiap bahagian mempunyai kepentingan yang tertentu iaitu bahagian A adalah berkaitan dengan maklumat umum yang lebih menjurus kepada latar belakang responden yang memfokuskan kepada aspek jantina, umur, taraf pendidikan dan sektor pekerjaan manakala bahagian B adalah mengenai kemudahan \& perkhidmatan zakat dan bahagian C pula mengenai pengiklanan zakat. Seterusnya, bahagian D adalah berkaitan dengan penggunaan sistem e-zakat dan akhir sekali adalah mengenai proses permohonan zakat.

Jadual 1. Rangka soalan borang kaji selidik yang telah diagihkan

\begin{tabular}{ll}
\hline Bahagian & Bilangan Soalan \\
\hline A Maklumat Umum / Demografi & 15 \\
B Mengenai Kemudahan \& Perkhidmatan Zakat & 5 \\
C Mengenai Pengiklanan Zakat & 5 \\
D Mengenai Penggunaan Sistem E-Zakat & 5 \\
E Mengenai Proses Permohonan Zakat & 5 \\
\hline Jumlah & $\mathbf{3 5}$ \\
\hline
\end{tabular}

Sumber: Maklumat soal selidik

Bahagia A terdiri daripada soalan yang berbentuk pilihan jawapan manakala soalan yang disediakan pada bahagian B hingga E adalah dalam bentuk skala likert. Selepas itu, dalam menentukan keberkesanan, kaedah mencari nilai purata telah dibuat di antara lima skala yang terdiri daripada sangat tidak setuju (1), tidak setuju (2), tidak pasti (3), setuju (4) dan sangat setuju (5). Hasil kutipan data dianalisis dengan menggunakan perisian Statistical Package of Social Science (SPSS) versi 22. Jadual 2 menunjukkan hasil ujian kebolehpercayaan yang telah dijalankan ke atas persoalan kajian yang telah diedarkan di lapangan. Berdasarkan Jadual 2, ujian kebolehpercayaan terhadap soalan kaji selidik telah dijalankan mengikut kategori soalan yang tergolong dalam kelompok-kelompok pembolehubah seperti kemudahan \& 


\section{MUHAMMAD ADIB MOHD ZAKI, MOHD ALI MOHD NOOR, HAIRUNNIZAM WAHID \& MUHAMMAD SYAFIQ MUHAMAD SHAM}

perkhidmatan zakat, pengiklanan zakat, penggunaan sistem e-zakat dan proses permohonan zakat. Keputusan ujian dilihat berdasarkan nilai Crobach Alpha di mana kesemuannya dilihat mempunyai nilai yang melebihi 0.60 iaitu nilai kebolehpercayaan yang boleh diterima pakai.

Jadual 2. Hasil ujian kebolehpercayaan soalan kaji selidik

\begin{tabular}{lllll}
\hline Bahagian & $\begin{array}{l}\text { Mengenai } \\
\text { Kemudahan } \\
\text { \& Perkhidmatan } \\
\text { Zakat }\end{array}$ & $\begin{array}{l}\text { Mengenai } \\
\text { Pengiklanan } \\
\text { Zakat }\end{array}$ & $\begin{array}{l}\text { Mengenai } \\
\text { Penggunaan } \\
\text { Sistem E-Zakat }\end{array}$ & $\begin{array}{l}\text { Mengenai Proses } \\
\text { Permohonan } \\
\text { Zakat }\end{array}$ \\
\hline Bilangan item & 5 & 5 & 5 & 5 \\
Cronbach Alpha & 0.833 & 0.702 & 0.838 & 0.788 \\
\hline
\end{tabular}

Sumber: Maklumat soal selidik

Bagi tujuan analisis data dengan menggunakan regrasi logistik berbentuk binomial, data bagi setiap pembolehubah telah dikodkan semula kepada bentuk binomial iaitu 0 dan 1 di mana pengkaji menggunakan kaedah potongan nilai min bagi data yang melebihi nilai min telah dikodkan kepada 1 manakala sebaliknya adalah 0 . Fungsi model logit yang umum berbentuk seperti yang dinyatakan di bawah:

$$
\mathrm{P}_{\mathrm{I}}=E\left(Y=\frac{1}{x}\right)=\frac{1}{1 \div e^{-z}}
$$

Di mana:

$\mathrm{P}_{\mathrm{I}} \quad$ merupakan kebarangkalian responden bersetuju adalah $\mathrm{Y}=1$ dan tidak bersetuju adalah $\mathrm{Y}=0$

$\mathrm{Z}_{\mathrm{I}} \quad$ merupakan fungsi $\mathrm{f}(\mathrm{X})$ dengan $\mathrm{X}$ adalah faktor-faktor yang mempunyai hubungan.

Persamaan (1) juga boleh ditulis seperti bentuk dibawah:

$$
\mathrm{P}_{\mathrm{I}}=\frac{1}{1+e^{-z}}=\frac{e^{-\mathrm{z}}}{1+e^{-z}}
$$

Jika PI merupakan kebarangkalian untuk responden bersetuju $Y=1$ maka $Y=0$ adalah kebarangkalian bagi responden tidak bersetuju iaitu (1-P). Oleh itu, kebarangkalian tidak bersetuju adalah:

$$
\left(1-\mathrm{P}_{\mathrm{I}}\right)=\frac{1}{1+e^{-z}}
$$

Oleh itu, nisbah kebarangkalian untuk cenderung bersetuju adalah:

$$
\frac{\mathrm{PI}}{1-\mathrm{PI}}=e^{\mathrm{Z}}
$$

Dengan penggunaan natural log untuk persamaan (4) akan menghasilkan:

$$
\begin{aligned}
L=\operatorname{Ln}\left(\frac{P_{I}}{1-P_{I}}\right) & =\ln \left(e^{Z}\right) \\
& =Z_{\mathrm{I}}
\end{aligned}
$$




$$
=f(X)
$$

Oleh kerana skala setuju atau tidak dalam mengenal pasti faktor-faktor kesukaran permohonan zakat di Kawasan flat kos rendah Dun Batu, Lembah Pantai dan Setiawangsa mempunyai hubungan dengan banyak faktor, maka beberapa faktor yang berkaitan secara langsung dalam mempengaruhi kesukaran permohonan zakat telah dipertimbangkan. Antaranya adalah umur, taraf pendidikan, sektor pekerjaan, kemudahan \& perkhidmatan zakat, pengiklanan zakat, sistem e-zakat dan proses permohonan zakat. Berdasarkan kepada persamaan (5) di atas, maka model khusus yang bakal dianggarkan melalui kajian ini adalah:

\section{Model 1. Faktor-faktor kesukaran penduduk membuat permohonan zakat}

$$
\mathrm{L}=\frac{P_{\mathrm{I}}}{1-P_{\mathrm{I}}}=\beta_{0}+\beta_{1} X_{1}+\beta_{2} X_{2}+\beta_{3} X_{3}+\beta_{4} X_{4}+\beta_{5} X_{5}+\beta_{6} X_{6}+\beta_{7} X_{7}+\beta_{8} X_{8}
$$

Di mana:

L ialah log ke atas nisbah 'odds' keberkesanan terhadap X

$X_{1} \quad$ ialah jantina $(0=$ perempuan, $1=$ lelaki $)$

$X_{2} \quad$ ialah umur

$X_{3} \quad$ ialah taraf pendidikan

$X_{4} \quad$ ialah sektor pekerjaan

$X_{5} \quad$ ialah kemudahan \& perkhidmatan zakat $(0=$ kemudahan \& perkhidmatan zakat membantu pemohon, $1=$ kemudahan $\&$ perkhidmatan tidak membantu pemohon)

$X_{6}$ ialah pengiklanan zakat $(0=$ pengiklanan zakat membantu pemohon, $1=$ pengiklanan zakat tidak membantu pemohon)

$X_{7} \quad$ ialah sistem e-zakat ( $0=$ tiada kesukaran penggunaan sistem e-zakat, $1=$ ada kesukaran penggunaan sistem e-zakat)

$X_{8} \quad$ ialah proses permohonan zakat $(0=$ tiada kesukaran dalam proses permohonan zakat, $1=$ ada kesukaran dalam proses permohonan zakat)

Seiring dengan objektif kajian ini, faktor kesukaran diuji dengan melihat kepada faktor yang mendorong kesukaran permohonan zakat sama ada dari aspek umur, taraf pendidikan, sektor pekerjaan, kemudahan \& perkhidmatan zakat, pengiklanan zakat, sistem e-zakat dan proses permohonan zakat. Temuduga secara terbuka juga telah dijalankan bersama penduduk flat kos rendah untuk mendapatkan maklumat berkaitan dengan komen pengurusan zakat di Malaysia, pengalaman semasa membuat permohonan zakat dan persetujuan penduduk flat kos rendah berkaitan dengan perlantikan amil kariah di sekitar kawasan tempat tinggal mereka.

\section{Hasil kajian dan perbincangan}

Kajian ini melibatkan seramai 139 orang responden yang terdiri daripada penduduk yang tinggal di flat kos rendah di Kawasan Dun Batu, Lembah Pantai dan Setiawangsa. Berdasarkan Jadual 3, majoriti responden terdiri daripada lelaki iaitu seramai $75(54 \%)$ orang dan selebihnya adalah perempuan seramai $64(46 \%)$ orang. Kategori umur responden pula adalah terdiri daripada 20 tahun hinga 60 tahun dan ke atas. Penyertaan peringkat umur yang paling tinggi adalah pada usia 40 tahun hingga 49 tahun seramai 41(29.5\%) orang, diikuti dengan umur 50 tahun hingga 59 tahun seramai 27(19.4\%) orang dan 60 tahun ke atas seramai 26(18.7\%) orang. Seterusnya, pada usia 30 tahun hingga 39 tahun adalah seramai $24(17.3 \%)$ orang manakala 20 tahun hingga 29 tahun seramai $20(14.4 \%)$ orang dan $(0.7 \%)$ mewakili seorang responden yang berumur 20 tahun ke bawah. 


\section{MUHAMMAD ADIB MOHD ZAKI, MOHD ALI MOHD NOOR, HAIRUNNIZAM WAHID \& MUHAMMAD SYAFIQ MUHAMAD SHAM}

Jadual 3. Latar belakang responden

\begin{tabular}{|c|c|c|}
\hline Latar Belakang & Kekerapan & Peratus (\%) \\
\hline \multicolumn{3}{|l|}{ Jantina } \\
\hline Lelaki & 75 & 54 \\
\hline Perempuan & 64 & 46 \\
\hline \multicolumn{3}{|l|}{ Umur } \\
\hline 20 ke bawah & 1 & 0.7 \\
\hline 20 tahun hingga 29 tahun & 20 & 14.4 \\
\hline 30 tahun hingga 39 tahun & 24 & 17.3 \\
\hline 40 tahun hingga 49 tahun & 41 & 29.5 \\
\hline 50 tahun hingga 59 tahun & 27 & 19.4 \\
\hline 60 tahun dan ke atas & 26 & 18.7 \\
\hline \multicolumn{3}{|l|}{ Taraf Perkahwinan } \\
\hline Bujang & 21 & 15.1 \\
\hline Berkahwin & 96 & 69.1 \\
\hline Duda / Janda & 22 & 15.9 \\
\hline \multicolumn{3}{|l|}{ Tempoh Bermastautin } \\
\hline 30 tahun dan ke bawah & 108 & 77.7 \\
\hline 30 tahun dan ke atas & 31 & 22.3 \\
\hline \multicolumn{3}{|l|}{ Status Pekerjaan } \\
\hline Bekerja & 77 & 55.4 \\
\hline Belajar & 3 & 2.2 \\
\hline Tidak bekerja & 59 & 42.4 \\
\hline \multicolumn{3}{|c|}{ Pendapatan Bulanan Isi Rumah } \\
\hline RM1000 ke bawah & 9 & 6.5 \\
\hline RM1000-1999 & 29 & 20.9 \\
\hline RM2000-2999 & 21 & 15.1 \\
\hline RM3000-3999 & 12 & 8.6 \\
\hline RM4000-4999 & 2 & 1.4 \\
\hline RM5000 dan ke atas & 4 & 2.9 \\
\hline \multicolumn{3}{|l|}{ Pemilikan Aset } \\
\hline Ada Aset & 33 & 23.7 \\
\hline Tiada Aset & 106 & 76.3 \\
\hline \multicolumn{3}{|l|}{ Pemilikan Rumah } \\
\hline Penyewa & 84 & 60.4 \\
\hline Pemilik & 55 & 39.6 \\
\hline
\end{tabular}

Sumber: Maklumat soal selidik

Selanjutnya, majoriti responden adalah berstatus berkahwin iaitu seramai 96(69.1\%) orang dan seramai $22(15.9 \%)$ berstatus duda atau janda manakala selebihnya iaitu $21(15.1 \%)$ orang adalah bujang. Selepas itu, kebanyakan responden yang bermastautin selama 30 tahun dan ke bawah adalah 108(77.7\%) orang manakala 30 tahun dan ke atas seramai $31(22.3 \%)$ orang, dari segi status pekerjaan pula, kekerapan yang paling tinggi adalah bagi yang bekerja iaitu sebanyak 77(55.4\%) orang yang bekerja manakala tidak bekerja seramai 59(42.4\%) orang. Antara anggaran pendapatan bulanan isi rumah yang paling tinggi adalah sebanyak RM1000 hingga RM1999 iaitu 29(20.9\%) orang, diikuti dengan RM2000 hingga RM2999 adalah 21(15.1\%) orang, RM3000 hingga RM3999 seramai 12(8.6\%) orang, RM1000 ke bawah 9(6.5\%) orang manakala RM5000 dan ke atas seramai 4(2.9\%) orang dan akhir sekali RM4000 hingga RM4999 hanya seramai 2(1.4\%) orang sahaja. Seterusnya, penyelidik juga mengkaji pemilikan aset iaitu kajian menunjukkan bahawa jumlah responden yang tidak mempunyai sebarang aset seramai 106(76.3\%) 
orang manakala yang mempunyai aset seramai 33(23.7\%) orang. Akhir sekali jumlah penduduk yang masih menyewa adalah seramai $84(60.4 \%)$ orang dan selebihnya merupakan pemilik rumah tersebut.

Dalam mengkaji tahap kesukaran permohonan zakat, keputusan kajian ditunjukkan dalam Jadual 4. Berdasarkan Jadual 4, secara keseluruhannya responden merasa sukar untuk membuat permohonan zakat iaitu sebanyak 80.0 berbanding 78.3 yang tidak sukar.

Jadual 4. Taburan tahap permohonan zakat penduduk flat kos rendah

\begin{tabular}{|c|c|c|c|c|}
\hline \multirow{3}{*}{ Pemerhatian } & & \multicolumn{3}{|l|}{ Ramalan } \\
\hline & & \multicolumn{2}{|c|}{ Pembolehubah Bersandar } & \multirow{2}{*}{$\begin{array}{l}\text { Peratus yang } \\
\text { tepat }\end{array}$} \\
\hline & & Tidak Sukar & Sukar & \\
\hline \multirow{2}{*}{ Pembolehubah Bersandar } & Tidak Sukar & 54 & 15 & 78.3 \\
\hline & Sukar & 14 & 56 & 80.0 \\
\hline Peratus Keseluruhan & & & & 79.1 \\
\hline
\end{tabular}

\section{Sumber: Maklumat soal selidik}

Selanjutnya, kajian ini mengkaji kebarangkalian komponen kualiti hidup yang signifikan mempengaruhi proses kesukaran permohonan zakat di kawasan flat kos rendah. Kompenen yang akan dimasukkan ke dalam model regrasi logistik sebagai pembolehubah bebas (independent variable) adalah (1) umur, (2) jantina, (3) taraf pendidikan, (4) sektor pekerjaan, (5) pendapatan, (6) tempoh bermastautin, (7) kemudahan dan perkhidmatan permohonan zakat, (8) pengiklanan zakat, (9) proses permohonan zakat. Analisis kajian adalah seperti berikut:

Ujian padanan model: Dalam model 1, pembolehubah bersandarkan adalah responden tidak rumit untuk mengisi borang permohonan zakat dan menyediakan dokumen yang diminta, menunjukkan peratus yang tepat secara keseluruhan sebanyak 79.1 peratus dan ini menunjukkan model ini berada pada aras kesahan yang tinggi iaitu melebihi 50\% (Jadual 2). Merujuk kepada jadual 3, model 1 ini juga mendapati pembolehubah bersandar yang diterangkan oleh pembolehubah bebas sebanyak 38 peratus digambarkan oleh Cox \& Snell $\left(\mathrm{R}^{2}=0.389\right)$ dan 51 peratus ditunjukkan oleh Nagelkerke $\left(\mathrm{R}^{2}=0.518\right)$. Lantaran itu, ujian padanan model telah dilakukan dengan menggunakan ujian chi-square Hosmer dan Lemeshow yang menunjukkan nilai yang tidak signifikan iaitu bersamaan $2.817(d f=8)$ yang memberi makna bahawa model ini mempunyai padanan model yang baik.

Jadual 5. Hasil regresi

\begin{tabular}{lll}
\hline Pemboleh ubah & $\begin{array}{l}\text { Nilai Koefisien } \\
(\text { S.E) }\end{array}$ & Statistik Wald \\
\hline Konstan & $\begin{array}{l}4.084 \\
(1.342)\end{array}$ & 9.258 \\
& $\begin{array}{l}\text {-2.459 } \\
(0.837)^{* * *}\end{array}$ & 8.640 \\
\hline Umur & $\begin{array}{l}0.941 \\
(0.789)\end{array}$ & 1.422 \\
\hline Sektor & -0.453 & 0.731 \\
& $(0.530)$ & 0.002 \\
\hline Bermastautin & 0.022 & \\
\hline Pendapatan & $(0.576)$ & 0.118 \\
\hline Kemudahan \& Perkhidmatan Zakat & 0.159 & \\
\hline
\end{tabular}


MUHAMMAD ADIB MOHD ZAKI, MOHD ALI MOHD NOOR, HAIRUNNIZAM WAHID \& MUHAMMAD SYAFIQ MUHAMAD SHAM

\begin{tabular}{lll}
\hline & $(0.670)^{* *}$ & \\
\hline Pengiklanan Permohonan Zakat & 0.011 & 0.000 \\
& $(0.530)$ & 0.099 \\
\hline Penggunaan Sistem E-Zakat & -0.188 & 26.876 \\
\hline Proses Permohonan Zakat & $(0.597)$ & \\
& -2.774 & \\
\hline Hosmer dan Lemeshow $\left(\boldsymbol{x}^{2}\right)$ & $(0.535)^{* * *}$ & \\
Cox dan Snell $\mathbf{R}^{2}$ & 2.817 & \\
Negelkerke $\mathbf{R}^{2}$ & 0.389 & 0.518 \\
\hline
\end{tabular}

Nota: (1) ***,**, * masing-masing ialah signifikan pada aras keertian $1 \%, 5 \%$ dan $10 \%$

(2) Angka dalam kurungan adalah nilai statistik t.

Nilai koefisien: Hasil regrasi terhadap model 1 mendapati 2 pembolehubah yang signifikan pada aras keertian 1 peratus iaitu umur(0.003) dan proses permohonan zakat $(0.001)$ manakala kemudahan dan perkhidmatan permohonan zakat pula signifikan pada aras keertian 5 peratus iaitu 0.038 . Hal ini menunjukkan wujudnya hubungan yang positif antara umur, kemudahan dan perkhidmatan zakat dan proses permohonan zakat terhadap pemboleh ubah bersandar. Ini menggambarkan kenaikan 1 tahun pertambahan dalam umur akan menyebabkan penurunan kebarangkalian kesukaran membuat permohonan sebanyak 0.085. 1 unit pertambahan dalam kemudahan dan perkhidmatan zakat menyebabkan penurunan kebarangkalian kesukaran membuat permohonan sebanyak 0.249 dan 1 unit penambahbaikan dalam proses membuat permohonan menyebabkan penurunan kebarangkalian kesukaran membuat permohonan sebanyak 0.062. Kebiasaannya jenis bantuan zakat yang gemar dimohon oleh penduduk Flat Kos rendah adalah bantuan kewangan bulanan, makanan, yuran persekolahan dan perubatan kerana bantuan-bantuan tersebut sangat dekat dengan lumrah kesusahan yang mereka alami sepertimana yang telah dibuktikan oleh kaji selidik yang diterbitkan oleh UNICEF. Namun permohonan yang paling sukar semestinya permohonan bantuan kewangan bulanan kerana ia melibatkan jumlah yang sangat besar bagi menampung perbelanjaan bulanan keseluruhan isi rumah.

\section{Cadangan dasar}

Berdasarkan hasil kajian di atas menunjukkan faktor umur merupakan mempengaruhi kesukaran seseorang dalam membuat permohonan zakat. Hal ini terbukti benar apabila kebanyakan warga emas tidak arif mengenai proses pengisian borang permohonan bantuan tersebut. Selain itu, ia juga menunjukkan bahawa kebanyakan orang yang sudah meningkat usianya tidak lagi mengambil berat berkenaan dengan proses pengisian borang tersebut kerana ia beranggapan pengisian borang bantuan itu terlalu rumit hingga menyebabkan mereka berasa malas untuk berurusan dengan pejabat zakat. Lebih merumitkan lagi apabila kini ia melibatkan permohonan secara dalam talian yang jauh lebih sukar bagi golongan ini untuk membuat permohonan. Isu ini bukan sahaja terjadi dalam sistem zakat sahaja bahkan banyak lagi sistem-sistem lain yang tidak selari dengan pembangunan semasa penduduk tempatan. Lantaran itu, golongan ini seharusnya didedahkan secara formal oleh pengawai zakat dan memberikan sedikit kelonggaran kepada mereka yang kurang terdedah dengan perkembangan teknologi semasa supaya setiap kelas masyarakat dapat menikmati keadilan bersama.

Selepas itu, apabila anak-anak dalam sesebuah isi rumah itu sudah meningkat dewasa dan bekerja maka orang tua mereka ini merasakan pemberian wang zakat tersebut tidak perlu diendahkan lagi. Terdapat kebarangkalian bahawa mereka merasakan pendapatan anak-anak yang diberikan setiap bulan sudah mencukupi bagi menampung perbelanjaan harian mereka. Walhal hakikatnya ia tidak mencukupi kerana dapatan kajian Khalid et al. (2018) menunjukkan pendapatan isi rumah penduduk flat kos rendah masih 
lagi rendah bagi menghadapi kos sara hidup yang semakin meruncingkan. Bahkan yang lebih parah lagi apabila warga emas di Malaysia mengalami masalah keselamatan sosial yang tidak mampan. Jomo (2018) menyifatkan para pekerja di Malaysia hanya mampu meneruskan hidup dalam tempoh kurang daripada 10 tahun dengan wang simpanan yang mereka perolehi daripada Kumpulan Wang Simpanan Pekerja (KWSP). Oleh itu, anak-anak harus peka terhadap kebajikan ibu bapa kerana jikalau orang tua mereka sememangnya layak memperolehi bantuan zakat sewajarnya mereka membantu ibu bapa mereka untuk membuat permohonan bantuan tersebut. Walaupun kemungkinan bantuan tersebut tidak banyak namun ia sedikit sebanyak dapat meringankan bebanan kos tanggungan yang dihadapi. Justeru, lebihan pendapatan yang diperolehi oleh anak-anak boleh disimpan untuk kegunaan keselamatan social mereka pada masa akan datang seperti perbelanjaan kos perubatan bagi penyakit-penyakit yang kritikal.

Kemudahan dan perkhidmatan zakat sangat penting bagi mengurangkan kesukaran permohonan zakat dalam kalangan penduduk flat kos rendah. Tidak dapat dinafikan bahawa pusat zakat telah pun melaksanakan pelbagai jenis program zakat seperti Karnival Yez (Year End Zakat) di Wangsa Maju dan mengadakan operasi kaunter zakat bergerak di pelbagai tempat namun perlaksanaannya haruslah lebih meluas dengan mengutamakan aspek pengagihan zakat kepada golongan asnaf. Hal ini kerana program tersebut mampu menyebarkan informasi, memudahkan proses pengurusan zakat serta dapat menangkis perasaan segan silu di antara pemohon dan pengawai zakat. Selain itu, kakitangan pusat zakat perlu turun ke padang untuk mengenal pasti keberadaan golongan asnaf yang layak menerima zakat dan pada masa yang sama juga dapat mengemas kini butiran peribadi penerima zakat. Pusat zakat juga perlu membuat kempen kesedaran kepada orang miskin untuk memohon zakat dengan menyatakan akibat kegagalan pengagihan zakat kepada golongan asnaf sepertimana yang dilakukan dengan begitu kerap oleh pusat zakat ke atas akibat orang yang tidak membayar zakat. Hal ini kerana pemohon dan pembayar zakat masing-masing memainkan peranan mereka bagi membantu meningkatkan lagi keberkesanan pengagihan zakat di Malaysia.

Seterusnya, kelonggaran dalam proses permohonan zakat juga mampu mengurangkan kesukaran dalam membuat permohonan zakat. Tidak dapat dinafikan bahawa masih terdapat segelintir masyarakat yang masih tidak tahu-menahu mengenai proses sistem surat menyurat yang disediakan oleh pusat zakat. Seterusnya, proses rantaian perlu diperkemaskan lagi bagi institusi-institusi kerajaan yang mempunyai kaitan rapat dengan pusat zakat. Syarat-syarat permohonan juga perlu diteliti semula seperti keperluan gambar passport yang memerlukan kos yang tinggi dan kad pengenalan anak-anak yang dilihat tidak relevan kerana maklumat tersebut boleh didapati jika pusat zakat membuat semakan dengan Jabatan Pendaftaran Negara. Selain itu, proses permohonan zakat juga akan lebih mudah jika terdapat kaunter zakat di setiap masjid yang berhampiran dengan kawasan penduduk flat kos rendah kerana masjid merupakan tempat berhimpunya para jemaah Islam dalam sebarang aktiviti, dalam masa yang sama ia dapat mengimarahkan lagi masjid tersebut sepertimana yang telah dilaksanakan oleh Lembaga Zakat Selangor. Perkara ini sangat penting kerana ia dapat memudahkan urusan di antara kedua-dua belah pihak untuk membuat permohonan zakat tanpa perlu mengambil masa lebih lama untuk ke pusat zakat.

Akhir sekali, majoriti $84 \%$ penduduk flat kos rendah bersetuju dengan perlantikan penolong amil kariah di sekitar kawasan tempat tinggal mereka. Penolong amil kariah ini telah pun dilaksanakan dengan meluas di negeri Selangor dibawah tadbir urus Lembaga Zakat Selangor. Pelaksanaannya menunjukkan kesan yang positif lantas sewajarnya perlu dilaksanakan oleh semua Lembaga Zakat negeri masingmasing. Tugas utama penolong amil kariah ini adalah bagi menjalankan banci ke atas orang beragama Islam dalam suatu kariah masjid tertentu yang layak menerima zakat dan fitrah. Selain itu, mereka juga akan memantau kebajikan asnaf fakir, miskin dan muallaf serta menjalankan apa-apa tugasan lain sebagaimana yang diarahkan oleh Lembaga zakat. Lantaran itu, dengan adanya penolong amil kariah ia dapat menyelesaikan masalah penerima zakat yang berasa segan untuk berurusan dengan kakitangan zakat yang mereka tidak kenali kerana ia melibatkan aib keluarga itu sendiri. Selepas itu, mereka juga 


\section{MUHAMMAD ADIB MOHD ZAKI, MOHD ALI MOHD NOOR, HAIRUNNIZAM WAHID \& MUHAMMAD SYAFIQ MUHAMAD SHAM}

mengalami kekangan waktu atas faktor komitmen menjaga anak-anak dan mencari punca rezeki hingga menyebabkan mereka tiada masa untuk memohon zakat. Oleh itu, proses permohonan zakat seharusnya lebih menyenangkan kerana ia melibatkan orang yang terpinggir dan tidak mempunyai autoriti dalam segala aspek kehidupan. Perkara ini sangat mustahak bagi mengelak daripada isu ini menjadi lebih parah yang disebabkan oleh sistem birokrasi yang mengada-ngada sehingga orang atasan dengan semudah bicara mampu membuat onar dengan kebajikan rakyatnya sendiri.

\section{Kesimpulan}

Kesimpulannya, kelonggaran dalam permohonan zakat terhadap golongan asnaf perlu diteliti semula supaya golongan yang disasarkan dapat menikmati hak yang sewajarnya mereka perolehi dengan tidak mengabaikan kapasiti bagi setiap peringkat pemohon zakat sama ada di dalam bandar atau luar bandar bagi perlaksanaan kemudahan dan perkhidmatan serta proses permohonan zakat dapat berjalan dengan lancar. Perkara ini sangat penting kerana ia akan mempengaruhi kredibiliti kepercayaan daripada pihak pembayar dan penerima zakat itu sendiri. Selain itu, kajian berkaitan dengan had kifayah zakat juga perlu dikaji semula setelah Jabatan Perangkaan Malaysia (2020) mengumumkan tingkat kemiskinan yang baru iaitu iaitu sebanyak RM2208 supaya bantuan zakat dapat mencapai golongan sasaran yang selari dengan realiti isu kemiskinan di Malaysia. Lantas, kemungkinan besar wujudnya kesukaran permohonan tersebut adalah kerana prasyarat yang sangat ketat dari segi jumlah pendapatan ketua keluarga yang tidak selari dengan realiti isu kemiskinan di Malaysia. Oleh itu, medium zakat sewajarnya menunjukan teladan yang baik dalam menyumbang kepada kebajikan masyarakat bukannya menjadikan satu khabar berita yang buruk kepada rakyat jelata sepertimana yang telah terjadi terhadap isu Tabung Haji yang disabitkan dengan pelbagai skandal rasuah dan salah guna kuasa dalam kalangan elit yang jadong bak kata Alatas (1992) (Bernama, 2018).

\section{Rujukan}

Alatas, H. (1992). Intelektual masyarakat membangun. Dewan Bahasa dan Pustaka, Kementerian Pendidikan Malaysia.

Aziz, W. N. A. W. A., Ahmad, F., \& Hanif, N. R. (2011). Pembasmian Kemiskinan Bandar ke arah Bandar Inklusif dan Sejahtera: Cabaran Kuala Lumpur. Journal of Surveying, Construction and Property, 2(1), 107-124.

Bernama. (2018, December 19). Pegawai kanan Tabung Haji direman berhubung pengubahsuaian rumah. Retrieved August 16, 2020, from Astro Awani Online: http://www.astroawani.com/beritamalaysia/pegawai-kanan-tabung-haji-direman-berhubung-pengubahsuaian-rumah-193945

Department of Statistics Malaysia. (2020). The Key Findings: Income, Poverty, Inequality, Expenditure, Basic Amenities..

Embong, M. R., Taha, R., \& Nor, M. N. M. (2013). Role of zakat to eradicate poverty in Malaysia. Jurnal Pengurusan (UKM Journal of Management), 39, 141-150.

Eza Ellany, M. Rizal \& M. Sabri, 2014. Prestasi Kecekapan Agihan Kewangan dan Bukan Kewangan dalam Kalangan Institusi Zakat di Malaysia. Jurnal Ekonomi Malaysia, 48(2), 51-60.

Hairunnizam Wahid, Sanep Ahmad \& Radiah Abdul Kader. (2010). Pengagihan Zakat oleh Institusi Zakat kepada Lapan Asnaf: Kajian di Malaysia. Jurnal Pengurusan JAWHAR, 4(1), 141-170.

Hairunnizm Wahid, Sanep Ahmad, Mohd Ali Mohd Noor, Maryam Abd Rashid. (2017). Prestasi Kecekapan Pengurusan Kewangan Zakat dan Agihan Zakat: Perbandingan Antara Majlis Agama Islam Negeri di Malaysia. Jurnal Ekonomi Malaysia, 51(2), 33 - 46.

Hairunnizam Wahid. (2018). Pengurusan zakat di Malaysia: isu dan cabaran kontemporari. Pusat Penyelidikan Ekonomi dan Kewangan Islam (EKONIS-UKM). 
Jomo, K. S. (2017, Oktober 25). Most Malaysians cannot afford to retire. Retrieved July 18, 2019, from Malaysiakini Online: https://www.malaysiakini.com/news/399433

Khalid, M. A. (2014). The colour of inequality: Ethnicity, class, income and wealth in Malaysia. MPH Group Publishing Sdn. Bhd.

Khalid, M. A., Rosli, Z., Fatimahtul, S. N., Halim, M. A. \& Akbar, E. S. (2018). Children Without: A study of urban child poverty in low cost flats in Kuala Lumpur. Retrieved from https://www.unicef.org/malaysia/FINAL-REPORT-1.pdf

Majlis Agama Islam Wilayah Persekutuan. (2013, January 16). Kutipan Zakat Wilayah Persekutuan 2013 RM492.01 Juta. Laman Rasmi Majlis Agama Islam Wilayah Persekutuan. Retrieved from http://www.maiwp.gov.my/i/index.php/berita-maiwp/392-kutipan-zakat-wilayah-persekutuan-2013$\underline{\mathrm{rm} 492-01-\text { juta }}$

Rashid, M. A., Wahid, H., \& Ahmad, S. (2018). Analisis Faktor Penentu Kualiti Pengurusan Zakat: Kajian Terhadap Lembaga Zakat Selangor (LZS) di Sepang. Journal of Fatwa Management and Research, 11(1), 27-44.

Muhammad Syukri Salleh. (2006). Penyetempatan pengagihan zakat: satu cadangan teoritis. Dlm. Zakat: Pensyariatan, Perekonomian \& Perundangan, disunting oleh Hailani \& Abdul Ghafar. Bangi: Penerbit Universiti Kebangsaan Malaysia.

Mohamad Uda Kasim. (2005). Zakat: Teori, Kutipan dan Agihan. Kuala Lumpur: Utusan Publications \& Distributors Sdn.

Noor, A. H. M., Rasool, M. S. A., Ali, R. M. Y. S. M., \& Rahman, R. A. (2015). Efficiency of Islamic Institutions: Empirical Evidence of Zakat Organizations' Performance in Malaysia. Journal of Economics, Business and Management, 3(2), 282-286.

Rif'at Abd Latif Masyhur. (2010). Zakat Penjana Ekonomi Islam. Kuala Lumpur. Al-Hidayah Publication.

Habitat, U. N. (2003). Slums of the world: the face of urban poverty in the new millennium. Nairobi: United Nations Human Settlements Programme.

Za'aba, Z. A. A. (2015). Mencapai ketinggian dunia akhirat. Kuala Lumpur: Dewan Bahasa dan Pustaka.

Zayas F.G. (2003). The Law and Institution of Zakat. Kuala Lumpur: The Other Press. 